\title{
Erratum: The Regulation of DNA Damage Tolerance by Ubiquitin and Ubiquitin-Like Modifiers
}

Frontiers Production Office *

Keywords: DNA damage tolerance, translesion synthesis, ubiquitylation, SUMOylation, ISGylation, PCNA

\section{An Erratum on}

The Regulation of DNA Damage Tolerance by Ubiquitin and Ubiquitin-Like Modifiers by Cipolla, L., Maffia, A., Bertoletti, F., and Sabbioneda, S. (2016). Front. Genet. 7:105. doi: 10.3389/fgene.2016.00105

Reason for Erratum:

Due to the typesetting error, the Greek symbols $(\zeta, \eta, \kappa, \mathbf{\imath})$ got mixed-up throughout the proof in the original publication. The corrections have been made in all the corresponding instances as mentioned in the table below, also it has been highlighted in the supplementary material for reader's convenience.

The publisher apologizes for this error, and this error does not change the scientific conclusions of the article in any way.

The original article has been updated.

OPEN ACCESS

Approved by:

Genetics Editorial Office

Frontiers, Switzerland

${ }^{*}$ Correspondence:

Frontiers Production Office production.office@frontiersin.org

Specialty section:

This article was submitted to

Cancer Genetics,

a section of the journal

Frontiers in Genetics

Received: 30 September 2016 Accepted: 30 September 2016 Published: 30 September 2016

Citation:

Frontiers Production Office (2016) Erratum: The Regulation of DNA Damage Tolerance by Ubiquitin and Ubiquitin-Like Modifiers.

Front. Genet. 7:184

doi: 10.3389/fgene.2016.00184

\begin{tabular}{|c|c|c|}
\hline Line number & Changed from & Changed to \\
\hline 421 & Poln & polk \\
\hline 719 & Poln & polı \\
\hline 722 & Poln & polı \\
\hline 725 & Poln & polı \\
\hline 728 & Poln & polı \\
\hline 747 & Poln (both the occurrences) & polk \\
\hline 751 & Poln & polk \\
\hline 753 & Poln & polk \\
\hline 804 & Poln & polı \\
\hline 807 & Poln & polı \\
\hline 812 & Poln (both the occurrences) & Pols \\
\hline 818 & Poln & Polל \\
\hline
\end{tabular}

\section{SUPPLEMENTARY MATERIAL}

The Supplementary Material for this article can be found online at: http://journal.frontiersin.org/ article/10.3389/fgene.2016.00184

Copyright (C) 2016 Frontiers Production Office. This is an open-access article distributed under the terms of the Creative Commons Attribution License (CC BY). The use, distribution or reproduction in other forums is permitted, provided the original author(s) or licensor are credited and that the original publication in this journal is cited, in accordance with accepted academic practice. No use, distribution or reproduction is permitted which does not comply with these terms. 